\title{
'Come all you bold heroes, give ear to my Song': Sport, drink and sex
}

Come one and all, both great and small/With voices loud and clear,

And let us sing bless Billy the King/Who bated the tax on beer.

'A Drop of Good Beer' c.1830 from J Ashton, Modern

Street Ballads, 1888

\section{Some preliminary comments}

ENGLAND WAS A singing nation, but for many years, popular song, particularly the broadside ballad, was treated with a combination of condescension and contempt. Lyrics were dismissed as either luridly sensational (especially when dealing with crime and punishment) or banal and formulaic (especially when dealing with romance); tunes were seen as basic and performers untutored. With few exceptions, it was not until the emergence of social history as a distinctive area of academic study that popular songs were taken seriously as 'the voice of the poor.'The sheer scale of their production, and their lasting popularity, highlights their importance to an understanding of popular mentalities and socio-political relationships. Popular songs fulfilled a variety of purposes: entertainment; emotional expression; education, via the transmitting attitudes and values; and evaluation, through social and political commentary. In this and the following chapter the focus will be on song as observation; but there were also nonsense songs and tongue- 
twisters simply meant to entertain and others that gave voice to a range and mix of emotions. This chapter will focus on two areas. First, sport and drinking; second, those dealing with love, courtship, marriage and betrayal. The following chapter will be devoted to a further two categories: crime and punishment and social and political commentary.

The complexities of interpreting song are considerable. While there is much surviving evidence relating to words and tunes, there is virtually none relating to performance; and yet performance could enhance or subvert 'authorial' intent. Likewise, the intended messages of writer and performer were not necessarily the same as the responses of their various audiences, since 'meanings ... are never set, they are always dependent on cultural context and interpretation. ${ }^{11}$ Audiences - more accurately members of an audience -brought values and assumptions, some unspoken, which themselves varied over time and place.

\section{Leisure and pleasure}

Many songs, predominantly from a male perspective, celebrated a range of popular leisure activities, and the physical attributes of the participants. Further, these songs often equated personal qualities of courage and determination with national characteristics. Yet this was a time when plebeian leisure activities were being condemned and, as in the case of cockfighting, criminalised, and in which concerns with 'order and decorum,' embodied in the 'new police,' led to a range of pressures on working-class behaviour. The continuing popularity of these songs, and the distinctive physical masculinity celebrated in them, highlight the limits of the new 'respectable' masculinity, with its emphasis on man as the protector of the weak, including women, children and animals, and the rejection of violence. Old leisure activities, including blood sports, were stubbornly defended well into the nineteenth century. ${ }^{2}$

\section{Sporting songs}

The range of sporting activities celebrated in popular song was wide - cricket, rowing, wrestling, even bull-running - but 
hunting and boxing featured large. Tributes were paid to 'noble foxhunting' and 'hunting the hare' as well as cockfighting. ${ }^{3}$ Such songs were still being printed in the third quarter of the nineteenth century. The poet and local historian, Ammon Wrigley of Saddleworth, noted in his 'Old Songs of the Inns,' men's preferences for hunting and poaching songs with 'the chorus singing ... like a pack of hounds in full cry." Although there is a distinction to be made between songs about gentlemanly hunts (on horseback) and plebeian hunting (on foot), which was to be found particularly in northern England, particularly Cumberland, Westmorland and the West Riding of Yorkshire, there are a number of common themes. The participants were regularly described as 'brave boys' or 'bonny lads,' even though women were to be found at hunt. The hunt itself was almost invariably exhilarating. As 'The Morning Is Fair' made clear, 'the best of all pleasure is hunting the hare.' Equally praiseworthy were the hounds. Their canniness and tenacity were praised in 'Noble Foxhunting' (sometimes known as 'Dido, Bendigo'), a song to be found from Cumberland to Cornwall. More locally, 'Old Snowball' paid tribute to a beagle of the Holme Valley hunt. ${ }^{5}$ Even the victims were celebrated. Cocks were lauded for their fighting spirit, foxes and hares for their ingenuity and elusiveness.

Such songs spoke to an older, Corinthian masculinity that was increasingly criticised from the late eighteenth century onwards. Its clearest celebration came in the songs about prize-fighting, appealing to 'you lovers of the manly art, wherever you may be.' Strength, endurance and fortitude were the 'virtues' praised in ballads such as 'The Newcastle Champion. ${ }^{6}$ The heroic individual, commonly eulogised as a lion, was presented as the embodiment of true Englishness. 'Lines on the Great Fight between Tom Sayers, Champion of England, and Bob Brettle of Birmingham' referred to Sayers as 'the noble champion [whose] manly determination [made him] champion of proud England, and the conqueror of all.' His defeated opponent, Brettle, was 'a man of courage bold [noted for] mighty deeds of manly art,' denied victory only by 'an accidental fall'. Likewise, in "Sayers' and Heenan's great fight,' the protagonists (again) fought like lions and with 'pluck and courage stout, each proved himself a man.' There was 
more at stake in this fight. John Carmel Heenan was an IrishAmerican and the bout was billed as a clash between the USA and Britain. One ballad, 'Sayers and Heenan's Struggle For the Championship and $\mathcal{C}^{400}$ ' was blatantly set to the tune 'Come All You Gallant Britons Bold.'7 Another, 'The Death of Sayers,' claimed 'Tom was a gallant hero/No-one could him subdue,' conveniently glossing over the fact that the fight was declared a draw after 42 rounds, with many claiming that Heenan had been cheated of a victory. However, the balladeer was keen to praise Sayers' courage 'like a Briton bold and true." Even more brazen was the praise heaped on Tom Cribb after a controversial fight in 1811. The fight had added frisson as the American challenger was a former slave. Ballads, such as 'Crib [sic] and Molineaux', delighted in the Briton's triumph without mentioning that his victory owed much to a crowd invasion in which Molineaux was injured.

\section{Drinking songs}

The most celebrated leisure activity was drinking. The social significance for men of experience of the ale house (and later beer house) has long been recognized. Singing, particularly collective, convivial singing, was a key element. Some songs were tied to specific work events, notably harvest ('The Barley Mow'), sheep-shearing ('Black Ram'), or key dates in the calendar, notably Easter and Christmas, but others were a more general celebration of conviviality. The centrality of entertainment is most clearly seen in songs like 'Come Landlord Fill the Flowing Bowl,' with its rousing chorus of 'For tonight we'll merry, merry be ... tomorrow we'll be sober,' or in the many variants of 'Jones' Ale'. ' It is no coincidence that the participants, varying in number and trade, in these songs are 'jovial' and 'good fellows. ${ }^{10}$ Furthermore, 'jolly good ale' (and even porter) is praised, not least for its healthy properties - 'Banish draught, pills and potions, they'll nothing avail/No draught so effectual as Roddam's good ale. ${ }^{11}$ In 'Bring Us In Good Ale,' a wassail song dating back in printed form to the fifteenth century, singers reject beef, bacon, mutton, capons and more, demanding 'For our Blessed Lady's sake, bring us in good ale. ${ }^{12}$ In other songs, beer becomes a good friend, not least in 'Good Ale' in which it is 'my darling ... my joy both night and morning.' ${ }^{13}$ 
A smaller number of ballads offered a less celebratory view of drink. Drinking becomes a coping mechanism in the face of the harshness of life and the inevitability of death. 'For the cares of this life are but grief and vexation/To death we must all be confined' says the drinker in 'With My Jug in One Hand.' Drink and be merry for tomorrow we die is a recurring theme. But as well as consolation there was also a sense of defiance of death and damnation. The much-travelled, heavy-drinking 'Roisin the Beau' views his final journey with equanimity. 'When I'm dead and laid out on the table/A voice you will hear from below/Saying "Send down a hogshead of Whisky"/ To drink with Old Roisin the Beau.' Death is imminent.'I feel that great tyrant approaching, /That cruel remorseless old foe,' but, game to the end, 'I lift up my glass in his honour, /Take a drink with Old Roisin the Beau.'

The dangers of alcohol are explicitly stated in the relatively small number of temperance ballads, such as those produced by John Harkness, the Preston printer and temperance advocate. 'In the Days I Went Drinking a Long Time Ago' is a predictable catalogue of poverty, loss of employment, eviction and an unhappy wife and family, which is only reversed when the one-time drunkard finally gives up his dissolute lifestyle. 'Wholesome Advice to Drunkards' highlighted the exploitation of the drinking man. The 'blooming landlady, so saucy and fat' cajoled money from the poor for the benefit of her sons and daughters with their 'gold watches, rings, so dandified, they to boarding school must go.' Similarly, in 'A Warning to Drunkards,' landlords were seen as rapacious, taking every last penny before kicking out the drunken wretch,' while their wives 'drest in silk and bombazine [have] boas, rings and handsome pins/just like some foreign Princess or Queen.'The content of such ballads is unsurprising. More interesting, and perhaps more influential, were those non-temperance ballads which pointed up the dark side of drinking. To what extent singers and audiences identified with the sentiments expressed in these songs is unknowable but difficult issues were raised. There is a modern ring to those songs in which the sole purpose appears to be drinking to excess, drowning sorrows and care and escaping, albeit temporarily, the burden of everyday life. At times, as in 'The Drunkard Reformed' or 'The 
Drunkard's Dream' there is a sense of remorse at the negative impact on the individual, family and friends, which leads to a positive resolution; but not always. 'The Alewives Invitation to Married-men and Bachelors' paints a grim picture of the fate awaiting those who delighted in 'drinking and ranting.' 'But now all is consumed wasted and gone/He may look o'er the bare walls and make his last moan.' Similarly, in 'Good Ale,' it is you [good ale] that makes my friend and foes/It is you that makes me wear old clothes.' It led to marital problems - 'And if my wife should me despise/How soon I'd give her two black eyes' - but exercised an unbreakable hold. The final verse runs: 'You have caused me debts and I've often swore/I never would drink strong ale anymore. /But you, for all that, I'll forgive/ And I'll drink strong ale as long as I live.'

The impact of drink on marital relationships is treated in a variety of ways. The most positive, such as 'Little Brown Jug,' paint a picture of good-natured harmony. Husband and wife live in 'a neat little cottage we call our own [and where] we have lots of fun. ${ }^{14}$ More often than not, drink is a source of discord and conflict. ${ }^{15}$ The 'perils' of a drunken wife are recounted in 'A Married Man's Advice to the Batchelor' and 'The Drunken Wife' but the drunken, violent husband was a more common figure. The opening lines of the chorus of 'The Wife's Lamentation' are unambiguous. 'Drunk, drunk from morn to night, in a public house is he, /Smoking, drinking, then comes home at night and wallops me.' As well as causing domestic violence, Gammon has argued that drink was seen as a means of resolving conflict, either between partners, as in 'Bang Her Well Peter' and 'Poor Joe the Miller' or between neighbours.as in 'John Appleby.' ${ }^{16}$ On closer examination, it is not obvious that this is the case. In 'Bang Her Well Peter,' the central issue is who wears the trousers. Peter accuses his wife of adultery (on two occasions) and the couple come to blows. Dorothy asks for mercy and suggests 'fetch up some beer and let us agree.' Having promised 'no more will I cuckold or strike you my dear,' she asks, 'come give me a kiss and a glass of good beer.'The ballad concludes with the following lines:'Now bang her well Peter, /Now Peter has won, the breeches he'll wear' - more a triumph of patriarchal authority than of domestic harmony. Similarly, the resolution of conflict between 'Poor 
Joe' and his wife raises more questions than it answers. Having been railed at by his wife for spending 'his bob' on 'good ale,' Peter brings home 'pots of ales' with which he 'made his wife well fuddled,' after which 'they kissed and hugged, she did not rail/But went to bed and cuddled.'Thereafter, 'they then would both together sup/together they would be muddle/Drunk as sows they'd have their sup/And reel to bed and cuddle,' Nor does 'John Appleby' simply end 'when all the neighbours are invited in for a merry, home-brewed-ale-drinking party.' In the final verse the neighbours run in to end the quarrel between John and his wife but, instead join in the drinking, leaving 'ne'er a drop' as they 'banged the barrel about, pulled out the spigot too.'The ballad ends on a bleak note: 'We'll all get drunk to night for what have we else to do.' A triumph for drunken oblivion. Occasionally, as in 'The Drunken Husband,' the wife is able to exact some revenge, initially by pawning his clothes, later by literally beating him at his own game. 'She blacked his eyes and broke his nose, /You villain, she cried, no more of your airs, /Then slap she bundled him over the stairs.' More often, wives lamented their married state, wishing to be single again, or that their husbands were dead.

\section{Songs about sex, love and marriage}

Many songs referred to matters sexual. Some were ribald, some were cautionary, some celebrated courtship and true love, some did not. Although many songs reflected a male perspective, a greater female voice was to be heard than with sporting songs. Further, in these songs one can detect changing attitudes and values. Old songs that were once acceptable fell out of common usage or were excluded from the mainstream; new songs treated matters in a different, more acceptable manner. Nowhere is this more clearly seen than in the decline of the bawdy song.

\section{Bawdy and betrayal}

If Francis Place is to be believed, 'Such [bawdy] songs as even 35 years ago produced applause would now [1819] cause the singer to be rolled in the mud. ${ }^{17}$ Bawdy songs, relying on euphemism and innuendo, as well as explicit and 'vulgar' 
language, and treating sexual encounters humorously, had a long tradition. Both 'Tom Tinker' and 'The Travelling Tinker,' in Pills to Purge Melancholy. were explicit in describing the delights of sex, for men and women and also young and old. ${ }^{18}$ Among the songs included in Place's collection, 'A Pretty Maid She to the Miller Would Go' and 'Gee-ho Dobbin' were examples of occupational songs related to sex, relying upon references to grinding corn, the click-clack of stones and 'driving being my trade,' while 'A Hole to Put Poor Robin In' and 'Morgan Rattler' were more explicit. ${ }^{19}$

Bawdy songs operated in a variety of ways. There was the vicarious thrill of entering an underworld with its cant and flash language but also the sensationalism surrounding sexual scandal, especially in high places. 'The Naughty Lord \& the Gay Young Lady, Damages, $\mathcal{E}^{1} 10,000$.' was included in Charles Hindley's Curiosities of Street Literature, as late as 1871. There was also the celebration of sexuality, commonly emphasising male conquest and pleasure, with sex likened to the hunt, most clearly seen in 'The Keeper.' The eponymous figure carries, under his arm, a bow 'all for to shoot a merry little doe.' In fact, depending upon the variant, he chances his arm with five, even seven such creatures. ${ }^{20}$ The song, learned by generations of schoolchildren after its bowdlerization by Cecil Sharp, grew out of the eighteenth-century song 'The Frolicksome Farmer' (with its all-purpose line ('Tis of a brisk young farmer, in ---shire did dwell') whose actions were unambiguously predatory and sexual. Female sexual pleasure was also to be found, notably 'Oyster Nan [who] sighed for copulation'.

In an age when men and women across the social spectrum were well aware of puns and double meanings, there was considerable scope for combining a celebration of sexuality with humour in a variety of euphemistic descriptions; but an acceptable euphemism for one, might be offensive to another. The offended became more vocal from the late-eighteenth century onwards, bringing condemnation and prosecution. According to Richard Hayward, an associate of Place, 'obscene ballads and songs in praise of thieving were the only ones sung about the streets' in the 1780s but they generated a moral panic with the Daily Universal Register condemning 'obscene ballads sung about the streets by a set of wretches, so very low as to 
be incapable of feeling anything but the stroke of a whip' and called for action in 1785. ${ }^{21}$ Moral entrepreneurs like Patrick Colquhoun likewise demanded a legal clamp-down on street singers and reformers like Hannah More produced wholesome alternatives on a massive scale. The question arises: why did attitudes change at this time? For much of the eighteenth century there was little concern with songs, which were thinly disguised descriptions of men and women enjoying sex. Many a 'fine fiddle' was played, not to mention equally phallic flutes and 'merry bagpipes'; ploughmen ploughed literal and metaphorical furrows, while milkmaids similarly plied their skills; many a nightingale sang sweetly for women whose amorous romping had left them with grass-stained 'green gowns.' Popular songs reflected and reinforced prevailing views of sexuality. In the third quarter of the eighteenth century (and before), there were cultural stereotypes - the ploughman and the milkmaid - of a healthy and fertile peasantry, which were not at odds with medical treatises, which contrasted a sexually healthy countryside with enfeebled, if not impotent, aristocrats and urban dwellers. From the late-eighteenth century onwards, there was a problematic and pessimistic view of an immoral and overpopulated country. ${ }^{22}$ Reformers like Place spoke of 'the song ... and lewd plays and interludes [which were] all calculated to produce mischief' by which he meant 'want of chastity in girls. ${ }^{23}$ Immorality and criminality were often explained in terms of the corrupting influence of popular culture. However, the problematizing of popular culture by moral entrepreneurs and improving radicals did not necessarily mean, pace Place, that bawdy songs had disappeared or were suppressed. Rather they were only driven from public spaces. Perhaps the most striking aspect of Place's recollections of life in and around his father's public house was that songs like 'Sandman Joe' were sung, particularly on Saturday nights, 'in an open space at the back of St. Clements in the Strand at the front of an alehouse door call'd the Crooked Billet by two women ... amidst roars of Laughter. ${ }^{24}$ And even when singing took place indoors, 'the parlour doors [were] thrown wide open [so] that whoever was in the bar and the tap room might hear every word. ${ }^{25}$ Further, these songs were performed, without shame, by 'respectable tradesmen' and their performances were 
met with clapping of hands and rapping of tables. In similar vein, was the popularity of 'The Black Joke,' a well-known song (and tune ${ }^{26}$ ) widely known for its bawdy connotations, and used in theatrical entr'actes, featuring comic and vulgar peasant dances, in London and Dublin. In addition, it appeared in numerous eighteenth-century collections, many of which were aimed at a 'middling sort' market. ${ }^{27}$

By the 1820s and 1830s bawdy songs were less common on the streets - and some may have lost their bawdy connotations - but they were still to be heard in song-and-supper clubs and similar venues, and also in the penny gaffs, so hated by Mayhew. Shocked by the songs, he was appalled by 'one scene yet to come, that was perfect in its wickedness.' Although the tune is not named, the description of 'a ballet began between a man dressed up as a woman, and a country clown ... [in which] the most disgusting attitudes were struck, the most immoral acts represented, without one dissenting voice' is consistent with other accounts of the 'Black Joke. ${ }^{28}$

Such is the frequency of sexual encounters that it would be easy to suggest that popular songs, not simply celebrated but also reflected a world of sexual liberation; but this would be misleading. While many songs spoke of pleasure, there were words of warning, albeit delivered light-heartedly at times. Having 'tossed and tumbled' all night with 'a fair maid,' the eponymous 'gentleman soldier' makes clear that 'a wife I have already and children I have three.' Furthermore, nine months later, 'the poor girl she brought shame. She had a little militia boy but didn't know its name.' In another song, 'the brave grenadier' 'plays such merry tunes on [his] long fiddle' as he and his fair maid sat down 'to hear the nightingale sing' that his fair maid asks, 'play me one tune more.' However, on being asked to marry, the soldier (again) confesses to having 'a wife at home in my own country/And she is the fairest maid that you ever did see.' Generously, should he return, 'it will be in the spring and we'll both sit down together to hear the nightingale sing.' Soldiers may have been particularly unreliable but seducers (and deserters) are to be found across the social spectrum as well as across the range of occupations. These songs serve a warning. As John Clare bluntly observed, 'the common ballad teaches men betray. ${ }^{29}$ One solution offered in 
these songs of seduction and abandonment was to take care 'Keep Your Hand Upon Your Little Ball of Yarn.' Another was to get married.

\section{Marriage}

Popular songs did not fall into discrete categories. Drinking songs dealt with marriage and showed that it was not a guaranteed route to happiness, particularly for women, but even sober husbands could be a disappointment. 'The Sandgate Lassie's Lament' is one of the best-known and eloquent laments - 'He's an ugly body, a bubbly body/An ill-faced hideous loon; / I have married a keelman/And my good days are done.' - but it was one of several 'wish I were single again' songs. ${ }^{30}$ Equally problematic were marriages to inadequate, often old men. Having described failed stratagems - 'Each night when to bed he goes/I throw one leg right over him, / And my hand I clap between his thighs/But I can't put any courage in him.' - the long suffering wife in ' $\mathrm{O}$ Dear O, advises 'fair maids 'where're you be, /Don't have a man before you try him.'There was also a sense of justified revenge for bad behaviour. The woman in 'The Silly Old Man' has no doubt her husband is a 'clown' but, in making him 'wear horns as long as a stag,' she and her lover will 'cuckold the miser and steal his gold bag.' Not surprisingly, there is a strong sense of male fear and dishonour found in the various 'cuckold' songs. There are also several songs in which philandering husbands are outwitted, usually by wives disguising themselves as servant girls. In their different ways, these negative depictions of marriage are another form of song-as-warning. The dangers of a hasty, mismatched marriage, or of unthinking and selfish behaviour, are real, and the consequences severe, and to be avoided. The implicit moral is that men and women should not have irresponsible dalliances that resulted in illegitimate children, husbands should be faithful and thoughtful, and wives dutiful. In this regard, such ballads were as much part of the maintenance of morality as the better known communal activities, such as 'rough music' and 'riding the stang,' which survived in certain parts of the country well into the nineteenth century.

However, there were songs - easily derided as romanticized and unrealistic - which paint a positive picture of love, courtship and marriage. More songs extolled the benefits of 
married life from a male (rather than female) perspective, as in 'The Charms of a Good Little Wife' or 'A Woman's the Pride of the Land,' though the paired ballads 'Worth of a Husband' and 'Worth of a Woman' see benefits for both parties. Some songs, such as 'Matrimonial Bliss,' combined an awareness of the trials of married life with its rewards, concluding 'Say what you will there's no joy in this life/Like that of a man who can boast a good wife.' Others, like the oft-printed 'John Anderson, My Jo,' celebrated (however sentimentally) the joys of a lifelong partnership.

\section{Some concluding observations}

Ultimately popular songs, understood in context, provide a partial if tantalising insight into the thinking and feeling of generations of men and women for whom little direct evidence exists. Given the range of songs relating to sport, drink and sex, the different ways in which themes were treated and shifts in values over time, there are no simple conclusions to be drawn. However, several points deserve emphasis. Many of these songs were conservative in outlook. Sporting songs, celebrating hunting and boxing and praising physical attributes, perpetuated an older masculinity well into the nineteenth century that was increasingly at odds with the respectable model of the sensitive, caring and protective new man of late-Georgian and early Victorian England. Drinking songs, likewise, often celebrated a male conviviality more akin to eighteenth century aristocratic masculinity. Although some were less celebratory, they still praised stoicism, especially in the face of death. But some songs recognised the negative impact of drinking on interpersonal relationships. There was also a continuing moral conservatism about many of the songs about sex, with men and women warned against irresponsible sex and hasty marriage. However, the decline (or relocation) of the bawdy ballad points to a change in popular attitudes more in keeping with the new 'respectable' morality. 


\section{Endnotes}

1 V Gammon, Desire, Drink and Death in English Folk and Vernacular Song, 16001900, Aldershot, Ashgate, 2008, p.4

2 See for example, C Hindley, Curiosities of Street Literature, London, Reeves \& Turner, 1871.For a more general discussion of the persistence of blood sports see D Taylor, Beerhouses, Brothels and Bobbies, University of Huddersfield Press, 2016, esp. pp.247-56 and G Woolnough, 'Blood Sports in Victorian Cumbria,' Journal of Victorian Culture, 19(3), 2016, pp.278-94

3 Among many hunting songs, 'Dido, Bendigo' was known from Cumberland to Cornwall, and was probably part of a longer 'Fox Chase' which was printed c. 1650 and is in the Roxburgh collection and appeared as a ballad printed by Pitts in the second quarter of the nineteenth century.'The Hare Hunting Song' (or 'The Morning Looks Charming') can be traced back to 'A Hunting Song' that was first published in 1747.Volume III of the Universal Songster, published in 1834, contained several hunting songs, including 'Let's Over the Hills, My Brave Boys, to the Chase,' 'Up, Up! My Brave Boys to the Chase' and 'Away, ye brave foxhunting race.'The latter first appeared as 'A Song in my New Comedy of the Bath' in volume II of D'Urfey's Pills to Purge Melancholy. 'The Cockfight' or 'The Bonny Grey' celebrated the fight between a 'charcoal black' and a 'bonny grey' but the fight is located variously in Holbeck, Liverpool, Oldham etc.!

4 A Wrigley, Rakings Up, 1949 quoted in S Roud, Folk Song in England, London, Faber \& Faber, 2017, p.325

5 The Holme Valley Beagles hunted hares on foot. C Ford \& C B Woodcock, Hunting in the Holme Valley: An Illustrated History of the Working Man's Hunt, 1986, Mirfield, published by the authors. Their song book (the first of which appeared in the late nineteenth century, includes obvious hunting songs, not least 'The Morning Is Charming' and 'Old Snowball' (in praise of one of the dogs) but also 'Highland Lassie' and 'Pace Egging Song' and, unsurprisingly, 'Pratty Flowers' aka 'The Holmfirth Anthem.'

6 The ballad celebrated the 1824 fight between Wallace and Dunn, both of whom fought 'like lions.'

7 Balladeers on the other side of the Atlantic responded in kind. See 'Ballad in answer to Sayers, England's pride.'

8 Sayers' bravery cannot be doubted. He was significantly shorter and lighter than his opponent.

9 The song, variously titled 'When Joan's ale was new' and 'When Jones' ale was new' can be traced back to 1594. It appeared in D'Urfey's Pills to Purge Melancholy and appeared as a printed ballad as late as the 1850s. The song is closely linked to 'Six Jovial Tradesmen' and 'The Three Merry Travellers,' which also appeared in varying forms, particularly regarding the tradesmen who appeared in the song. Pills to Purge Melancholy contains numerous celebratory drinking songs, such as 'A Toping Song,' 'The Good Fellows,' The Praise of Hull Ale,' which does not confine itself to Hull, nor ale, and 'The Presbyter's Gill,' a cumulative songs more familiar in the form of 'The Barley Mow.' 'Come Landlord Fill the Flowing Bowl' was a later song, probably dating from the 1820 s. 
10 Women do make occasional appearances. The landlord's daughter gets kissed 'twixt nose and chin' while the landlord's wife appears as 'a buxom lass who joins in harmony' in some versions.

11 Quoted Gammon, Desire, Drink and Death, p.115

12 Words and music of this song were included in J Ritson, Ancient Songs from the Time of King Henry the Third to the Revolution, London, J Johnson, 1790. Its continuing popularity saw it reprinted in T Wright, Festive Songs principally of the sixteenth and seventeenth centuries, London, Percy Society, 1848 and W Chappell, The Ballad Literature and Popular Music of the Olden Times, London, Chappell \& Co., 1859. In 1916, Gustav Holst arranged the song for four voices, Op.34, no. 4

13 There were also songs that featured more specific drinks, from Newcastle or Nottingham ale to Roddam's Fourpenny ale. Gammon, Desire, Drink and Death, p.104

14 From the Butterworth Collection and quoted in Gammon, Desire, Drink and Death, p.108

15 Several ballads, often sympathetic to men, depict strife arising from the wife's desire to wear the breeches.

16 Gammon, Desire, Drink and Death, p.127-8

17 Quoted in V Gatrell, City of Laughter: Sex and Satire in Eighteenth-Century London, London, Atlantic Books, 2006, p.457

18 Pills to Purge, volume 6, pp.265-7 and 296-7

19 'She had rosy cheeks and dimpled chin, /and a hole to put poor Robin in' and 'At every thrust, I thought she'd burst/With the terrible size of his Morgan Rattler.' Among the trades, tinkers cured cracks in the kettle, glovers and tailors whipped out their needles, and tanners could dress any hide. Again, the occupational/sexual song has a long history. D'Urfey included several well-known songs of this genre, such as 'The slow Men of London; Or the Widow Brown,' 'The Jolly Tradesmen,' and 'The Cries of London.'

20 In the final verse 'The seventh doe she prov'd with fawn, /And to the Keeper she made great moan, /Wishing he had but let her alone, /Among the leaves so green $\mathrm{O}$. In similar vein are the numerous songs involving the hunting of 'The Bonny Black Hare.'I says "My fair maiden, why mumble you so?/Can you tell me where the bonny black hare do go?"/Oh, the answer she gave me, her answer was "No"/But it's under me apron they say it do go/And if you'll not deceive me I vow and declare/We'll both go together to hunt the bonny black hare" "At which point the young maid "laid down with her face to the sky,' while the hunter took out his 'ramrod' and 'bullets.' D'Urfey, Pills to Purge Melancholy, pp.197-8 in which, punning on coney (a rabbit), 'Some in the Town go betimes to the Downs/To pursue the fearful Hare ... But my delight is a Cunny in the night, /When she turns up her silver Hair.'

21 Cited in V A C Gatrell, The Hanging Tree, Oxford University Press, 1994, p.125 and Daily Universal Register, 10 June 1785

22 R Ganev, 'Milkmaids, Ploughmen and Sex in Eighteenth-Century Britain,' Journal of the History of Sexuality, 16(1), 2007, pp.40-67

23 F Place, Autobiography cited in S Roud, Folk Song in England, London, Faber \& Faber, 2017, p.284 
24 F Place "Collections Relating to Manners and Morals; cited in I Newman, "Civilizing Taste: "Sandman Joe," the Bawdy Ballad, and Metropolitan Improvement' Eighteenth-Century Studies, 48(4), 2015, pp.437-56 at pp.443-4

25 Place, Autobiography cited in S Roud, Folk Song in England, London, Faber \& Faber, 2017, p.284

26 The tune probably pre-dates the lyrics and was sufficiently well-known to be used in several ballad operas, not least Gay's Beggar's Opera. Muzio Clementi wrote twenty-one variations, set for piano and harp. P Dennant, 'The 'barbarous old English jig': The 'Black Joke' in the Eighteenth and Nineteenth Centuries,' Folk Music Journal, 10(3), 2013, pp.298-318

27 Joke was one of several well-known euphemisms for female genitalia, which appeared in song and other literary forms. Others included coalhole and cuckoo's nest. The song itself can be interpreted in different ways (some have suggested it was an anti-Catholic satire) but the emphasis on nature and the enjoyment of sex by both men and women suggests it fits well with the notions of sexuality discussed above.

28 H Mayhew, The Penny Gaff,' P Quennell, ed., Mayhew's London, London, Spring Books, 1951, pp.86-90. Mayhew also mentions 'our Cyder-cellars, Coal-holes ... and such like places.'

29 Quoted in Gammon, Desire, Drink and Death, p.46

30 Some songs are far from straightforward. 'Still I love him' describes the poverty and harshness of married life with an uncaring man but 'still I love him, I'll forgive him; And I'll go with him wherever he goes.'There were also male songs of the 'I married a wife' genre that expressed similar sentiments 'when I was single my pockets did jingle/I wish I were single again.' 